\title{
EFFECTS OF Curcumalonga EXTRACTS ON MORTALITY AND FECUNDITY OF Bactrocera zonata (DIPTERA: TEPHRITIDAE)
}

\author{
Efeitos dos extratos de Curcuma longa sobre mortalidade e \\ fecundidade de Bactrocera zonata (Diptera: Tephritidae)
}

Abdul Rauf Siddiqi', Athar Rafi' ${ }^{1}$, Falak Naz', Rafique Masih ${ }^{2}$, Iftikhar Ahmad ${ }^{2}$, Ghulam Jilani ${ }^{2}$

\begin{abstract}
The peach fruit fly, Bactrocera zonata, is a significant pest of fruit and vegetable crops in South East Asia and Pacific region. Ccontrol strategies of fruit flies, relying chiefly on insecticides, have serious environmental consequences, disturbing the agroecosystem as well as eliminating natural enemies. This study was oriented at exploring the potential of turmeric, Curcuma longa, extracts to control the peach fruit fly. Freshly emerged female adults of Bactrocera zonata were continuously fed for 16 days on diet containing 1000, 500 and $250 \mathrm{ppm}$ of acetone extract of Curcuma longa separately in laboratory cages. The extract caused 85.00 , 66.67 and 56.67 percent mortality at 1000,500 and $250 \mathrm{ppm}$ respectively. The surviving females were mated and allowed to reproduce on clean guava fruits in separate cages. The inhibition in pupal progeny was 67.90, 60.74 and 51.96 percent in the flies fed on 1000,500 and $250 \mathrm{ppm}$, the inhibition observed in adult progeny was 84.68, 79.03 and 67.74 percent, respectively.
\end{abstract}

Index terms: Turmeric, peach fruit fly, Bactrocera zonata, solvent extracts, mortality.

\section{RESUMO}

A mosca do pêssego, Bactrocera zonata, é uma importante praga das frutas e produtos hortícolas no Sudeste Asiático e Pacífico. As estratégias de controle de moscas-das-frutas, que se baseia principalmente no uso de inseticidas, têm consequências ambientais graves, perturbando o agroecossistema, bem como eliminando os inimigos naturais. Este estudo foi orientado a explorar as potencialidades dos extratos de açafrão Curcuma longa para controle de B. zonata. Após a emergência, adultos de fêmeas de B. zonata foram continuamente alimentados, durante 16 dias, com dieta contendo 1000,500 e $250 \mathrm{ppm}$ de extrato acetônico de $C$. longa separadamente em gaiolas no laboratório. O extrato causou 85,00, 66,67 e 56,67 \% de mortalidade em 1000,500 e 250 ppm, respectivamente. As fêmeas foram acasaladas e postas para ovipositar separadamente em goiabas dentro das gaiolas. A inibição na progênie pupal foi $67,90,60,74$ e $51,96 \%$ nos insetos alimentados em 1000, 500 e 250 ppm, a inibição observada na progênie adulta foi $84,68,79,03$ e $67,74 \%$, respectivamente.

Termos para indexação: Cúrcuma, Bactrocera zonata, solventes de extracção e de mortalidade.

(Received in may 12, 2011 and approved in july 15, 2011)

\section{INTRODUCTION}

With around 40 pest species, the genus Bactrocera is considered the most significant group of insect pests from the economic point of view. It's most important species are Bactrocera dorsalis (Oriental fruit fly), Bactrocera curcubitae (Melon fly), Bactrocera oleae (Olive fruit fly), Bactrocera tryoni (Queesland fruit fly), and Bactrocera zonata (Peach fruit fly) (GARCIA, 2009)

The peach fruit fly Bactrocera zonata (Saunders) causes heavy damage to guava, mango, peach, apricot, loquat, etc. $B$. zonata is the most common and wide spread species not only in Pakistan but also in all fruit growing areas of the world (HASHMI, 1994). Therefore, it has attracted the attention of economic entomologists. In Pakistan, it is abundant in Punjab, Sindh and Balochistan and rare in northern foothills and Peshawar valley (MOHYUDDIM, 1989). B. zonata is the most abundant species in the Bannu district of North West Frontier Province (MARWAT; BALOCH, 1986).

Plants may provide potential alternatives to currently used insecticides because plant derivatives constitute a rich source of bioactive chemicals (WINK, 1993). Although the use of plant species to control insect pests has been in practice for centuries to a limited extent, only recently has interest been renewed in the pest management potential of natural products. Plants are nature's "chemical factories", providing the richest source of organic chemicals on Earth. Plant products have several uses in insect control (HASHMI, 2001).

Many plant extracts and essential oils are known to possess ovicidal, repellent and insecticidal activities

1Unité INSERM UMR-S 747, Pharmacologie, Toxicologie et Signalisation Cellulaire - Université Paris Descartes, 45 - Rue des Saints-Pères - 75006 Paris - França - abdul-rauf.siddiqi@parisdescartes.fr

${ }^{2}$ Insect Pest Management Programme - Institute of Plant \& Environmental Protection/IPEP - NARC Islamabad - Pakistan 
against insects (SCHOONHOVEN, 1981). Turmeric Curcuma longa is a tropical herb of Zingiberaceae family indigenous to southern Asia. The aromatic yellow powder from its mature rhizomes has been used as an ant repellent in India (WATT; BREYER-BRANDWIJK, 1962). It is an old practice in India and Pakistan to store rice or wheat by mixing it with $2 \%$ of turmeric powder (CHATTERJEE, 1980).

Jilani and $\mathrm{Su}$ (1983) showed that the petroleum ether extract of turmeric has also proved effective repellent and growth inhibitor against stored grain pests. Mostafa (1993) investigated the effect of extract of leaves of Thymus vulgaris, rhizomes of Curcuma longa and seeds of Piper nigrum (added to wheat grains) on the body weight, protein and lipid contents of 4th-instar larvae of Trogoderma granarium. The body weight, protein and lipid content of the treated larvae were significantly lower than in control larvae. Extracts of $C$. longa exhibited the greatest activity. Shakuntala and Thomas (2001) studied chemosterilant effect of A. calamus extracts on $B$. cucurbitae. Results revealed remarkable changes in the size and morphology of the reproductive organs of adult flies. Due to a combined effect of mating inhibition, reproductive suppression, and low survival, fecundity realization was not possible. Chowdhury (2001) found that azadirachtin, the major constituent of neem (Azadirachta indica), and turmeric oil, the major constituent of turmeric (Curcuma longa), exhibited significant insect growth inhibition and antifeedant activity against Spilosoma obliqua larvae.

Turmeric has been traditionally used for insect control in Indo-Pak Sub-Continent (JILANI, 1985; CHATTERJEE, 1980) turmeric extracts have also shown repellent and growth inhibitor against Tribolium castaneum (JILANI; SU, 1983; MOSTAFA, 1993)

Siddiqi et al. (2006) have demonstrated oviposition deterrent effects of turmeric extracts against $B$. zonata. Turmeric extracts suppressed egg laying as minimum numbers of pupae were recovered from the treated guava. The present studies are aimed at determination of repellent and growth inhibition effects of various extracts of turmeric on peach fruit fly, Bactrocera zonata.

\section{MATERIALS AND METHODS}

\section{Rearing of Fruit Fly}

The peach fruit fly was reared under controlled conditions at $28 \pm 1^{\circ} \mathrm{C}$ and $55 \pm 5 \%$ R.H. Guava fruit was exposed for 48 hours to the graved $B$. zonata females for egg laying. The infested fruits were transferred to glass jars (1-lb capacity) containing sand. The pupae were collected by sieving and kept in a cage for obtaining fruit fly adults of uniform age. For mass culture, the adults were provided with an artificial diet consisting of the ingredients as given below.

Two bananas, six eggs yolks, four table spoon honey, two table spoon Leaderplex: Vit B.complex syrup, one table spoon yeast and eight table spoon sugar.

\section{Preparation of Test materials}

Turmeric, C. longa ., rhizomes purchased from a local ayervadec shop were ground to a fine powder in an electric grinder. A weighed amount of turmeric powder was extracted separately with acetone, petroleum ether and ethanol on Soxhlet's extraction apparatus each for eight hours. The extracts were concentrated on rotary evaporator and finally made solvent free in a vacuum desicator.

\section{Bioassays on Survival and Reproduction}

Fifty pairs of freshly emerged flies were introduced in separate rearing cages. These flies were provided separately with 1000,500 and $250 \mathrm{ppm}$ of acetone extract of turmeric (being the most promising) in diet. The extract was mixed with artificial diet and fed continuously for 16 days to the newly emerged females. Dead flies in each treatment were daily counted. The flies fed on the treated/untreated diet were introduced in separate cages in three replications and allowed to oviposit on guava fruits. Number of pupae and adults formed were recorded to determine effect on reproduction. The data so obtained was statistically analysed using Duncan's multiple range test.

\section{RESULTS AND DISCUSSION}

\section{Mortality}

Percent mortality in freshly emerged fruit fly adults fed continuously for 16 days on diet containing 1000,500 and $250 \mathrm{ppm}$ of acetone extract of turmeric is given in Table 1 . Cumulative mortality after 4, 8, 12 and 16 days is depicted in Figure 1. It revealed that the flies fed on diet containing 1000 ppm acetone extract of turmeric showed 24.33 percent mortality after four days which increased to $32.67,62.33$ and 85.00 percent after 8,12 and 16 days respectively. The mortality was 16.33 , $18.67,42.33$ and 66.67 percent at $500 \mathrm{ppm}$ during the respective feeding periods and at $250 \mathrm{ppm}$ it was $8.33,16.33,36.67$ and 56.67 percent as against $2.33,4.67,26.33$ and 43.33 percent in control. There was almost insignificant mortality in fruit fly adults up to eight days in control.

The Table 1 revealed that fruit fly mortality was 85.00 percent at 1000 ppm followed by 66.67 and 56.67 percent at 500 and $250 \mathrm{ppm}$ as against 43.00 percent in control. Mortality of fruit fly fed on treated diet was directly related to the application rate of the extract which significantly increased with increase in concentration. 


\section{Fecundity}

Six pairs of the surviving fruit flies fed continuously for 16 days on diet containing acetone extract of turmeric each at 1000, 500, $250 \mathrm{ppm}$ were introduced in separate cages containing untreated guava for one week to study fecundity development.

The number of pupae and adults obtained from guava exposed to $B$. zonata having been fed 1000,500 and $250 \mathrm{ppm}$ concentration of acetone extract of turmeric is presented in table 2 . It revealed that minimum number of 46.33 pupae were recovered from the progeny of flies fed on diet containing $1000 \mathrm{ppm}$ of the extract. It was followed by 56.67 and 69.33 pupae in case of 500 and $250 \mathrm{ppm}$ respectively as compared with 144.33 in control (flies fed on normal diet). All the values were significantly different from each other Inhibition of pupae was 67.90, 60.74, and 51.96 percent at 1000,500 and $250 \mathrm{ppm}$ with reference to control.

The progeny of 19.00 and 26.00 adults were obtained from the pupae of flies fed on 1000 and 500 ppm concentration respectively which were significantly lower than 40.00 at $250 \mathrm{ppm}$ and from 124.00 in control. The number of adults at $500 \mathrm{ppm}$ were significantly lower than those at $250 \mathrm{ppm}$ and in control. The effect of the extract treated diet was evident even on the progeny adults as it considerably inhibited adult emergence from pupae. Maximum inhibition of 84.68 percent in adult emergence was observed in the progeny of flies fed at $1000 \mathrm{ppm}$ concentration followed by 78.77 and 67.74 at 500 and 250 ppm concentration, respectively.

Table 1 - Mortality of Bactrocera zonata adults during feeding on diet containing various concentrations of acetone extract of turmeric in cage containing 50 pairs.

\begin{tabular}{cc}
\hline Concentration $(\mathrm{ppm})$ & Percent Mortality \\
\hline 1000 & $85.00 \mathrm{a}$ \\
500 & $66.67 \mathrm{~b}$ \\
250 & $56.67 \mathrm{c}$ \\
Control & $43.33 \mathrm{~d}$ \\
\hline
\end{tabular}

Values followed by the same letters are not significantly different from each other ( $\mathrm{P} \leq 0.05)$, (Duncan's 1951) Multiple Range Test LSD=9.224 Average of 3 replications.

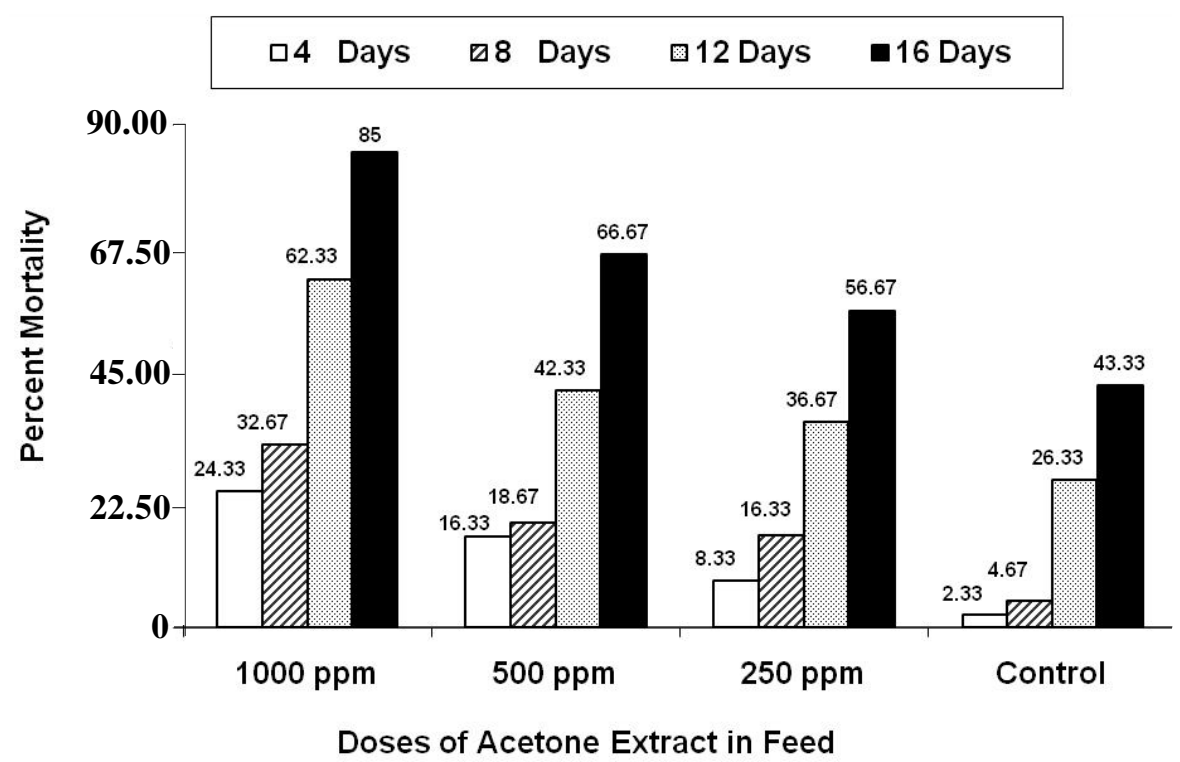

Figure 1 - Percent Mortality of B. zonata after days wise feeding at 1000, 500 and 250 ppm concentrations of acetone extract of turmeric in artificial diet.

Ciênc. agrotec., Lavras, v. 35, n. 6, p. 1110-1114, nov./dez., 2011 
Table 2 - Number of fruit fly Bactrocera zonata pupae and their inhibition obtained from feeding various concentrations of acetone extract of turmeric in cage containing six pairs of surviving fruit fly.

\begin{tabular}{ccccc}
\hline Concentration $(\mathrm{ppm})$ & \multicolumn{3}{c}{ Progeny } \\
& \multicolumn{3}{c}{ Pupae } & Adults \\
\cline { 2 - 5 } & No & Inhibition & No & Inhibition \\
\cline { 2 - 5 } & & & & \\
1000 & $46.33 \mathrm{~d}$ & $67.90 \mathrm{a}$ & $19.00 \mathrm{c}$ & $84.68 \mathrm{a}$ \\
500 & $56.67 \mathrm{c}$ & $60.74 \mathrm{~b}$ & $26.00 \mathrm{c}$ & $79.03 \mathrm{a}$ \\
250 & $69.33 \mathrm{~b}$ & $51.96 \mathrm{c}$ & $40.00 \mathrm{~b}$ & $67.74 \mathrm{~b}$ \\
Control & $144.33 \mathrm{a}$ & & $124.00 \mathrm{a}$ & \\
\hline
\end{tabular}

Values followed by the same letters are not significantly different from each other ( $\mathrm{P} \leq 0.05$ ), (Duncan's 1951) Multiple Range Test LSD=9.753(Pupae), 5.542(Inhibition) and 9.095 (Adults) , 6.155 (Inhibition) Average of 3 replications.

\section{CONCLUSION}

The findings of present studies have indicated that the acetone extract of turmeric significantly inhibits the growth and fecundity potential of peach fruit fly. Further studies need to be undertaken to develop pest control formulations from this material.

\section{ACKNOWLEDGEMENT}

The authors feel highly obliged to Agricultural Linkages Programme of Pakistan Agricultural Research Council, Islamabad for providing funds and facilities to undertake this piece of research work under an Umbrella project on "Integrated Management of Fruit Flies in Pakistan”.

\section{REFERENCES}

CHATTERJEE, P. B. In: GOLOB, P. A. W. D. J. . The Use of Plants and Minerals as Traditional Protectants of Stored Products. London: Tropical Products Institute, 1980.

CHOWDHURY, H.; WALIA, S.; DHINGRA, S. Bioefficacy of azadirachtin, turmeric oil and their mixture against Bihar hairy caterpillar, (Spilosoma obliqua Walk). Pesticide Research Journal , New Delhi, v. 13, n. 2, p. 165-172, 2001.

GARCIA, F. R. M. Fruit fly: biological and ecological aspects. In: BANDEIRA, R. R. Current trends in fruit flies control on perennial crops and research prospects. Kerala: Network, Transworld Research, 2009. p. 1-35.

HASHMI, A. A. Insect pest management, horticultural and forest crops. Islamabad: Pakistan Agricultural Research Council, v. 2, 1994. 664 p.
HASHMI, A. A. Integrated pest management in the 21st century. Islamabad: Pakistan Agricultural Research Council, 2001.

JILANI, G. Quality improvement in basmati rice in aging process. Proc. FAO Regional Field Workshop on Rice Grading. Lahore-Karachi, Pakistan: 1985. p. 192-211.

JILANI, G.; SU, C. F. Laboratory studies on several plant materials as insect repellents for protection of stored grains. Journal of Economic Entomology, Lanham, v. 76, p. 154-157, 1983.

MARWAT, N. K.; BALOCH. Methyl eugenol-a male fruit fly sex attractant. Pakistan Journal of Agricultural Research, Faislalabad, v. 7, p. 234, 1986.

\section{MOHYUDDIN, A. I. Integrated pest management of three mango pests. Multan, p. 137-141. 1989.}

MOSTAFA, T. S. Effect of certain plant extracts on body weight and some biochemical aspects of the khapra beetle, Trogoderma granarium Everts. Bulletin of the Entomological Society of Egypt. Economic series, Cairo, v. 20, p. 77-85, 1993.

\section{SCHOONHOVEN, L. M. First International Neem Conference: afterword. Proc. 1st Int. Neem Conf. Rottach-Egern 1981 p. 291-298.}

SHAKUNTALA, N.; THOMAS, J. Evaluation of chemostrilent effect of Acorus calamus L. extracts on melon fly, Bactrocera cucurbitae Coq. Journal of Tropical Agriculture, Serdang, Selangor, Malaysia., v. 39, p. 145-148, 2001. 
SIDDIQI, A. R. et al. Effect of turmertic extracts on settling response and fecundity of peach fruit fly (Diptera: Tephritidae). Pakistan Journal of Zoology Lahore, v. 38, n. 2, p. 131-135, 2006.

WATT, J. M.; BREYER-BRANDWIJK, M. G. The Medicinal and Poisnous Plants of Southern and Eastern
Africa. Edinburgh, Scotland: E. \& S. Livingstone, Ltd., 1962. 1062 p.

WINK, M. Production and application of phytochemicals from an agricultural perspective. In: VAN BEEK, T. A.; BRETELER, H. E. Phytochemistry and Agriculture. Clarendon,Oxford, v. 34, 1993. p. 171-213. 